\title{
Angiogenic Factors in Preeclampsia and Related Disorders
}

\author{
Ana Sofia Cerdeira ${ }^{1,2}$ and S. Ananth Karumanchi ${ }^{1,3}$ \\ ${ }^{1}$ Department of Medicine, Obstetrics \& Gynecology, Beth Israel Deaconess Medical Center, Boston, \\ Massachusetts 02114; and Harvard Medical School, Boston, Massachusetts 02114 \\ ${ }^{2}$ Gulbenkian Programme for Advanced Medical Education, 1067-001 Lisbon, Portugal \\ ${ }^{3}$ Howard Hughes Medical Institute, Chevy Chase, Maryland 20815 \\ Correspondence: sananth@bidmc.harvard.edu
}

During fetal development, the human placenta undergoes high levels of both angiogenesis and vasculogenesis. Additionally, the developing placenta undergoes a process of vascular mimicry (referred to as pseudovasculogenesis) as cytotrophoblasts convert from an epithelial to an endothelial phenotype. The initiation, maturation, and maintenance of the placental vasculature are of critical importance. Failure to do so can lead to adverse obstetric outcomes such as preeclampsia and/or intrauterine growth restriction (IUGR). Furthermore, the foundation of many aspects of adult health is laid in utero. In this context, normal placental function is not only critical for normal fetal development but can also permanently influence long-term health and disease. Understanding the mechanisms that regulate placental vasculogenesis and angiogenesis is therefore of critical importance. This chapter will focus on placental vascular development with a particular emphasis on the role of angiogenic factors in the pathogenesis of the maternal syndrome of preeclampsia and related disorders.

$T^{\mathrm{h}}$ he placenta is a remarkable organ, as it enables fetal development within a protective maternal environment (Cross et al. 1994). It performs an impressive array of functions ranging from anchoring the conceptus and preventing its rejection by the maternal immune system to providing critical exchange of gases, nutrients, and waste products. The placenta is a highly vascularized organ, containing both maternal and fetal blood vessels. The formation, maturation, and maintenance of the placental vasculature are of critical importance. Failure to do so can lead to adverse obstetric outcomes such as preeclampsia (Brosens et al.
1972), IUGR (Macara et al. 1996), and miscarriage (Meegdes et al. 1988). Furthermore, the placenta plays an active role in programming the fetal development, which, when deranged, may lead to disease in adult life (Irving et al. 2000; Barker 2003; de Rooij et al. 2010; Schulz 2010). Thus, although transient in existence, derangement of placental vessel formation can have a lifelong impact. Understanding the mechanisms that regulate placental vasculogenesis and angiogenesis is therefore of critical importance.

During embryonic development, the blastocyst separates into an outer polarized cell layer

Editors: Michael Klagsbrun and Patricia D'Amore

Additional Perspectives on Angiogenesis available at www.perspectivesinmedicine.org

Copyright (C) 2012 Cold Spring Harbor Laboratory Press; all rights reserved; doi: 10.1101/cshperspect.a006585

Cite this article as Cold Spring Harb Perspect Med 2012;2:a006585 
termed trophectoderm which gives rise to extraembryonic trophoblasts (the specialized epithelial cells of the placenta) and the nonpolarized inner cell mass that forms the embryo proper. Implantation of the blastocyst involves a complex interplay between the trophoblasts and maternal cells involving invasion of trophoblasts through the uterine wall to ultimately form the placenta.

Invading trophoblasts give rise to placental villi, the structural unit of the placenta. In addition, invasion of trophoblast creates open endings in the maternal vessels leading to maternal blood release into the intervillous space. Placental villi contain an inner layer of mononuclear cytotrophoblasts and an outer layer of continuous multinucleated cytoplasm referred to as syncytiotrophoblasts. It is in the spaces surrounding these structures that the maternal blood bathes fetal villi. Around day 13, first sprouting of trophoblast can be found protruding towards the intervillous space forming the first primary villi. Shortly after, extraembryonic mesoderm penetrates into the primary villi transforming them into secondary villi. The first fetal capillaries can be observed within this mesenchyme leading to the formation of tertiary villi (Huppertz 2008).

Continuing growth and differentiation of the trophoblast leads to branching of the villi and the shaping of the placental labyrinth where fetal-maternal exchange of oxygen and nutrients occurs. The ramifications of the villous trees can be subdivided in segments based on their caliber, stromal characteristics, vessel structure, and appearance during pregnancy as immature intermediate, stem, mature intermediate, and terminal villi (Castellucci et al. 2000). This chapter will focus on placental vascular development with a particular emphasis on the role of angiogenic factors in this process.

\section{PLACENTAL VASCULAR DEVELOPMENT}

\section{Placental Vasculogenesis}

Placental vascular development begins when cells from mesenchymal origin residing within the placental secondary villi differentiate into endothelial progenitor cells, which are believed to arise from the hemangioblast, a common precursor for endothelial and hematopoietic lineages. The subsequent assembly of these differentiated cells leads to the formation of primitive blood vessels.

In humans, placental vasculogenesis is evident by approximately 21-22 days postconception ( pc). At this stage, cords of hemangioblasts are present and some show primitive lumen formation. These cords further develop so that by day $32 \mathrm{pc}$ most villi show the presence of capillary structures (Demir et al. 1989). Lumen formation occurs via establishment of intercellular spaces between hemangiogenic cell cords (Demir et al. 1989, 2004). Fusion of intracytoplasmic vacuoles of few cells lead to small microvascular connecting tubes that establish bridge-like connections to the larger vessels, resulting in a primitive connecting network (Demir et al. 2004).

Hematopoietic stem cells, also derived from hemangiogenic stem cells, can be seen at 23$26 \mathrm{pc}$ in the primitive lumen, surrounded by endothelial progenitor cells (Demir et al. 2004). At this time, endothelial tubes are still isolated, as the placental vascular network is not yet connected to the embryonic vascular structures. This connection is established via the connective stalk (forerunner of the umbilical cord) around day $32 \mathrm{pc}$.

\section{Placental Angiogenesis}

During the angiogenesis phase, the endothelial tube segments formed through vasculogenesis will be transformed into an organized vascular network by means of branching angiogenesis through lateral sprouting and nonbranching angiogenesis through elongation of existing tubes.

From day 32 pc until the end of the 24th week, branching angiogenesis prevails. Multiple sprouting of microvessels produces a complex, multiply branched capillary web. From week 25 pc until term, patterns of villous vascular growth switch from the prevailing branching angiogenesis to a prevalence of nonbranching angiogenesis in which the capillaries 
predominantly increase in length by elongation of existing capillary loops. Under normal conditions it takes place in combination with branching angiogenesis (Kaufmann et al. 2004). By this time, mesenchymal villi start to develop into mature intermediate villi and then later start producing terminal villi. Analysis of proliferation markers at this stage reveals a decrease in trophoblast proliferation and an increase in endothelial proliferation along the entire length of these villous structures. The final length of these peripheral capillary loops exceeds $4000 \mu \mathrm{m}$ (Kaufmann et al. 1985, 1987) and they grow at a rate that exceeds that of the villi themselves, resulting in coiling of the capillaries. The looping capillaries bulge toward and obtrude into the intervillous space, and thereby contribute to formation of the terminal villi. Each of the former is covered by an external thin $(<2 \mu \mathrm{m})$ layer of trophoblast that contributes to the so-called vasculosyncitial membranes, separating the maternal and fetal circulations. These are the principal sites of exchange of gases via diffusion between mother and fetus.

Recently, Jirkovska and colleagues challenged the hypothesis that nonbranching angiogenesis prevails in the second half of pregnancy, reporting regular findings of branched terminal villous capillaries and blindly ending capillary sprouts in 3D reconstructions of images captured by confocal microscopy (Jirkovska et al. 2008). Further studies are necessary to clarify this.

Also important in these phases is the recruitment of supporting cells, pericytes, and smooth muscle cells which stabilize the developing vessels and are critical to the integrity of the developing vasculature. From the earlier stages, stromal cells are recruited as pericytes. First spots of basal lamina material are observed around week $6 \mathrm{pc}$, but a basement membrane with complete envelopment of the capillaries is only observed in the third trimester (Demir et al. 1989). In addition, stromal cells within the villi differentiate in a defined centripetal gradient with increasing cytoskeletal complexity from the superficial trophoblasts toward the blood vessels in the center of stem villi.
They range from proliferating mesenchymal cells (precursor cells) to highly differentiated myofibroblasts and possibly even myocytes and, together with stromal fibrosis, help to form thin media and adventitia-like structures in stem vessels in stem villi (Demir et al. 1989; Kohnen et al. 1996). These vessels are the forerunners of villous arteries and veins. A continuous transformation and ripening of the villous vessel system takes place until term (Fig. 1).

\section{Pseudovasculogenesis: Maternal Vascular Remodeling}

The formation of adequate maternal-placental circulation requires remodeling of maternal uterine spiral arteries. Invasion of the maternal spiral arteries by fetal cytotrophoblasts is a key event in this process. The created open endings of the maternal vessels release maternal blood into the placental labyrinth which subsequently flows around the placental villi and is drained by spiral veins.

During normal pregnancy, cytotrophoblast cells of the developing placenta migrate and invade the endothelium and the muscular layer of the maternal spiral arteries up to the inner one-third of the myometrium (Fig. 2). Along the process of invasion, the expression of a number of different classes of molecules such as integrins, cadherins, and metalloproteinases is modified in a process termed pseudovasculogenesis, since these cytotrophoblasts lose the epithelial phenotype and acquire an endothelial-like phenotype (Zhou et al. 1997b). Besides invading, cytotrophoblast cells replace the endothelial lining of the arteries, forming a pseudoendothelium compounding intriguing vessels, part fetal and part maternal. This process causes a remodeling of the artery wall, transforming the high-resistance muscular maternal arteries in high-flow, low-resistance vessels capable of providing adequate placental perfusion to sustain the growing fetus. This process peaks about 12 weeks and is complete near 20 weeks of gestation (De Wolf et al. 1980).

Placental oxygen tension has been suggested to be one of the major regulators of cytotrophoblast migration and differentiation (Genbacev 


\section{A.S. Cerdeira and S.A. Karumanchi}
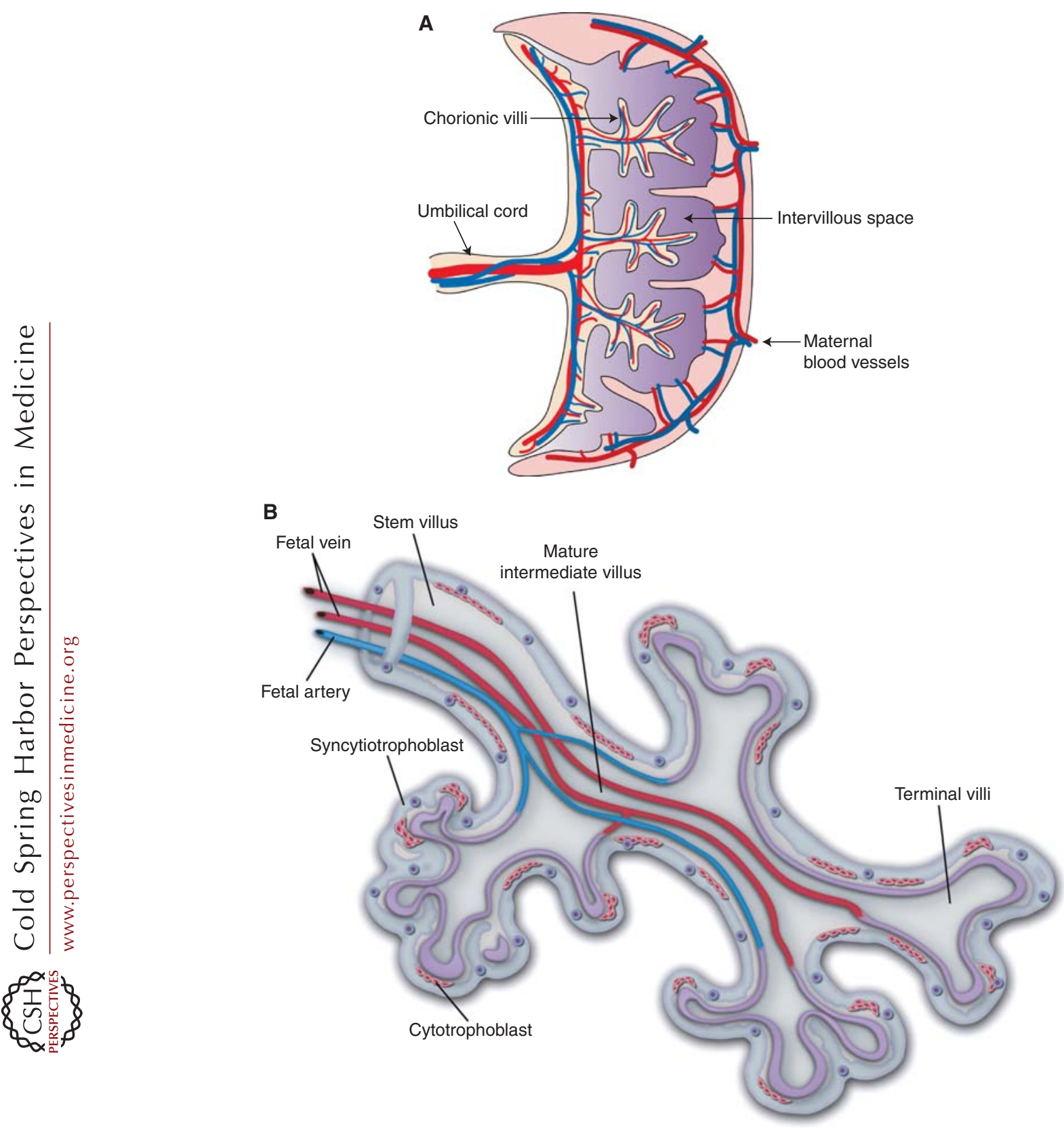

Figure 1. Representation of a normal human term placental $(A)$ and villous structure $(B)$. (A) Schematic representation of a normal human term placenta depicting the maternal and fetal circulation. $(B)$ Representation of a group of terminal villi. 

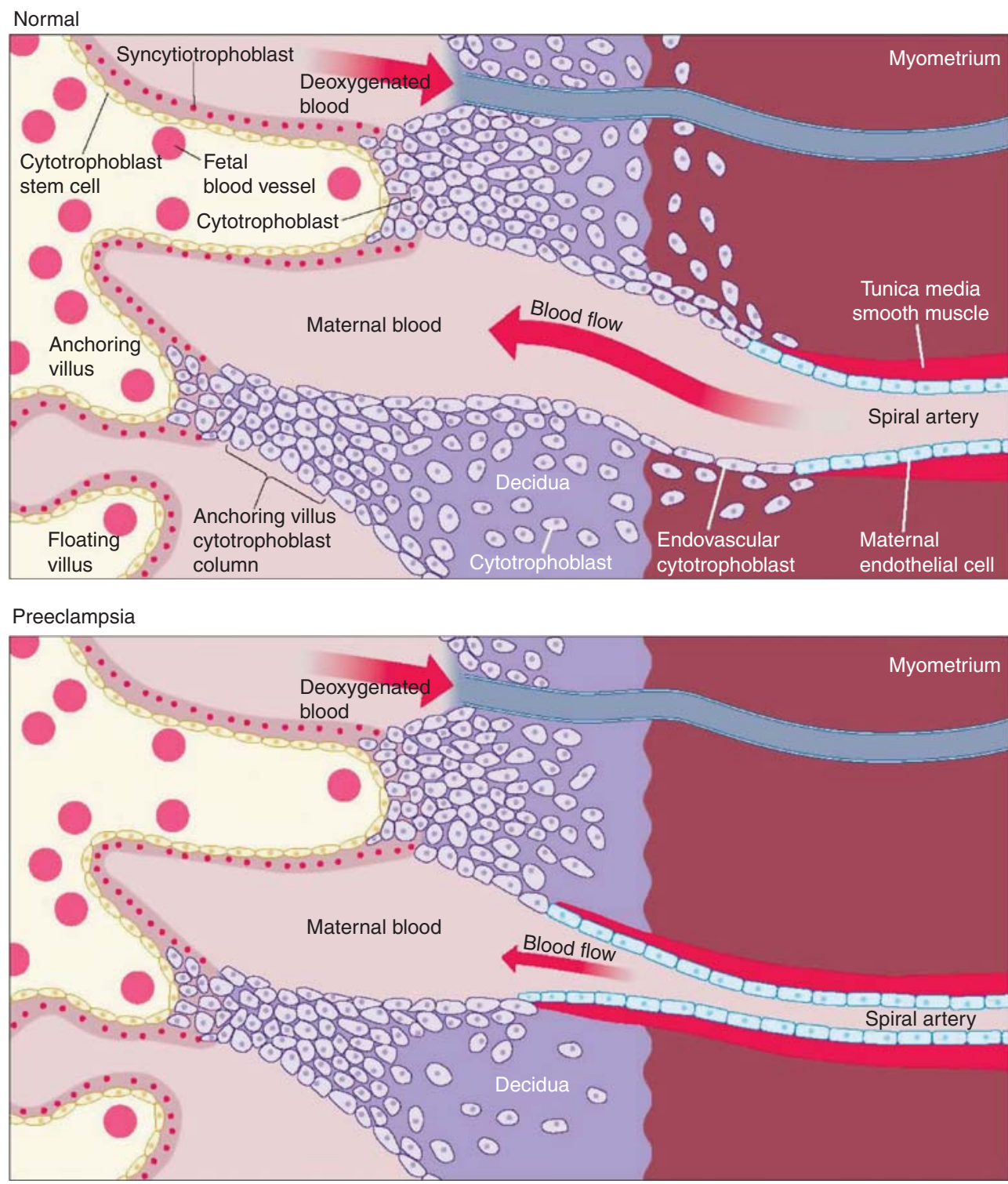

Figure 2. Placental vascular remodeling in health (upper panel) and in disease, preeclampsia (lower panel). In normal placental development, invasive cytotrophoblasts of fetal origin invade the maternal spiral arteries, transforming them from small-caliber resistance vessels to high-caliber capacitance vessels capable of providing placental perfusion adequate to sustain the growing fetus. During the process of vascular invasion, the cytotrophoblasts differentiate from an epithelial phenotype to an endothelial phenotype, a process referred to as "pseudovasculogenesis" or "vascular mimicry" (top). In preeclampsia, cytotrophoblasts fail to adopt an invasive endothelial phenotype. Instead, invasion of the spiral arteries is shallow, and they remain small-caliber resistance vessels (bottom). (Adapted from Lam et al. 2005; reprinted, with permission, from Wolters Kluwer Health (C) 2005.) 
et al. 1997); however, data regarding this topic are conflicting (James et al. 2006). It has also been hypothesized that decidual natural killer cells and/or activated macrophages may play a role in this process (Hanna et al. 2006). Finally, the hemodynamic changes that take place during spiral artery remodeling are considerable and have also been hypothesized to play a role in the spiral artery remodeling process (Osol and Mandala 2009).

\section{ANGIOGENIC FACTORS AS REGULATORS}

We still know very little about the details of the genetic program required to pattern the developing vasculature in the placenta. A number of candidates have been proposed, such as vascular endothelial growth factor (VEGF), angiopoietins, placental growth factor (PlGF), basic fibroblast growth factor, and transforming growth factor- $\beta$, etc. Among these, VEGF and its two receptors, Flt-1 and Flk-1/KDR have been shown to be crucial regulators of physiological and pathological blood vessel growth (Folkman and Shing 1992; Dvorak 2002) and, together with the angiopoietin family, have been the most extensively studied during placental development.

Members of the VEGF family include VEGF-A, VEGF-B, VEGF-C, VEGF-D, and PlGF. There are three VEGF family receptors, known as Flt-1, KDR, and Flt-4, as well as a soluble form of Flt-1 (sFlt-1, also referred to as sVEGFR1), which is generated by alternative mRNA processing and lacks the transmembrane domain and the cytoplasmic domain (Kendall and Thomas 1993; Huckle and Roche 2004; Thomas et al. 2007). VEGF-A, B, and PLGF bind to Flt-1, VEGF-A binds to KDR, and VEGF-C and D bind to Flt-4. PlGF and VEGF also bind to sFlt-1, which sequesters them from acting on their cognate membrane receptors. VEGF is highly expressed in the early human placenta. According to immunohistochemical and in situ hybridization studies, villous trophoblast and Hofbauer cells are the main source of this cytokine (Geva et al. 2002; Demir et al. 2004). Its cognate receptor KDR is present on endothelial cells or mesenchymal cells from which the endothelial cells differentiate (Clark et al. 1996; Vuckovic et al. 1996; Helske et al. 2001; Demir et al. 2004). Moreover, first trimester trophoblast and Hofbauer cells have been shown to secrete VEGF in vitro (Lash et al. 2010). Flt-1 was detected in the primitive vascular lumens and angiogenic cell cords (Demir 2009). This suggests that the initial steps necessary for building the primary vascular network are mediated by the VEGF family in a paracrine way. Immunohistochemical studies on the expression patterns of VEGF, PlGF, and their receptors in the placenta as well as maternal serum levels throughout pregnancy suggest an important role in villous angiogenesis. Expression of VEGF and KDR decline as pregnancy advances (Vuckovic et al. 1996) or moderately increase but less than placental weight does (Kaufmann et al. 2004). In contrast, expression of Flt-1 and PlGF increase towards term (Clark et al. 1998; Kumazaki et al. 2002). Maternal serum levels of free VEGF decline as pregnancy advances and sFlt-1 levels rise at 33-36 weeks. PlGF concentrations rise during pregnancy increasing markedly at 28-32 weeks (Levine et al. 2004).

A decreasing expression of VEGF and KDR, but increasing expression of PLGF, have been correlated with a switch from branching to nonbranching angiogenesis in the development of the placental villous angioarchitecture (Kaufmann et al. 2004). It has thus been hypothesized that the balance between VEGF, PlGF, and their receptors determines to some extent the geometry of the villous vascular bed (Kaufmann et al. 2004). VEGF is a known important inducer of branching angiogenesis (Carmeliet et al. 2009). PlGF is expressed in the normal placenta (Clark et al. 1998) and PlGF knockout mice are viable and show normal reproduction (Carmeliet et al. 2001). PlGF has been shown to be proangiogenic but also to inhibit branching angiogenesis in some cases (Bjorndahl et al. 2004; Fischer et al. 2008). In addition, it may also regulate other activities such as those of decidual natural killer cells (Tayade et al. 2007). sFlt-1 binds VEGF and PlGF and thus can inhibit their activity. Besides, sFlt-1 participates 
in the local guidance of nascent vessel sprouts (Kearney et al. 2004; Chappell et al. 2009) and thus may be able to directly regulate placental vessel formation.

Maturation of primitive endothelial tubes into mature blood vessels requires the recruitment of surrounding mesenchymal cells and their differentiation into vascular smooth muscle cells and pericytes (Carmeliet 2003). This process is largely mediated by the angiopoietins and their receptors Tie-2, PDGF, and TGF- $\beta$. In human placental tissues, expression of Ang-1, Ang-2, Tie-1, and Tie-2 has been detected at both protein and mRNA levels (Dunk et al. 2000; Goldman-Wohl et al. 2000; Zhang et al. 2001; Geva et al. 2002; Kayisli et al. 2006; Seval et al. 2008). Ang-1 mRNA increases with gestation (Geva et al. 2002; Wulff et al. 2002), whereas Ang-2 decreases. Ang-1 and Ang-2 have been primarily localized to trophoblast whereas moderate to weak immunoreactivity was observed in endothelial cells (Seval et al. 2008). Tie-1 and Tie-2 have been shown to be expressed in trophoblast and endothelial cells (Seval et al. 2008). Hofbauer cells express Ang-2, Tie-1, and Tie-2 (Kayisli et al. 2006; Seval et al. 2008). In the early placenta, Ang-1 showed immunoreactivity in endothelial cells of vessels within immature intermediate villi and no immunoreactivity in angiogenic cell cords of mesenchymal villi (Seval et al. 2008). At term, Dunk and colleagues localized Ang-1 to the surrounding perivascular tissues of the mature stem villi (Dunk et al. 2000). In primates, Tie-2 has been shown to be expressed at high levels in the endothelium of chorionic vessels and at low levels in the capillaries of the villi (Wulff et al. 2002). In humans, Kayisli and colleagues reported an increasing expression of Tie-2 in the endothelium parallel to vascular maturation (Kayisli et al. 2006). This is consistent with the role of Ang-1/Tie-2 as a vascular maturation and stabilizing agent. Moreover, the high levels of Ang-2 in early stages might prevent stabilization of the newly formed vessels, thus permitting the placental vessels to remain in a plastic state so that they can respond to the sprouting signal of VEGF, thus promoting branching angiogenesis
(Hashizume et al. 2010). Reports of localization of angiopoietins and its receptors at the time of vasculogenesis and initial stages of angiogenesis (namely in angiogenic cell cords) (Kayisli et al. 2006; Seval et al. 2008) raise the possibility that this signaling system may also regulate initial steps of vessel formation in the placenta.

The localization of receptors of VEGF and angiopoietin families in the trophoblast suggests that, in addition to regulation of vascular development, they may also regulate trophoblast function. Tie-1 and Tie-2 are expressed in the villous trophoblast, and Ang-2 has been shown to enhance trophoblast DNA synthesis and NO release whereas Ang-1 acts as a potent trophoblast chemotactic factor (Dunk et al. 2000). Ang-1 mRNA expression by decidual cells suggests that they may act as a chemoattractant to promote extravillous cytotrophoblast migration (Dunk et al. 2000). In addition, the high expression of Ang-2 in early gestation makes it a possible contributing factor for induction of maternal vascular transformation as it destabilizes the vasculature. Indeed, Ang-2 has been localized to trophoblast cells whereas Tie-2 is expressed in the maternal endothelium (Goldman-Wohl et al. 2000), indicating a paracrine mechanism for vascular remodeling. Decidual cells also express VEGF (Charnock-Jones et al. 1994; Cooper et al. 1995), whereas invading cytotrophoblasts express both VEGF and Flt-1 (Charnock-Jones et al. 1994; Cooper et al. 1995; Clark et al. 1996). The initial phases of extravillous cytotrophoblast differentiation take place within columns of trophoblast cells which are formed in the upper part of villi anchored to the maternal decidua. Flt-1, KDR, Tie-1, and Tie-2 were shown to be expressed within these columns and to have a differential expression pattern throughout the column (Zhou et al. 2002; Kayisli et al. 2006). Under in vitro conditions, VEGF-A induces cytotrophoblast invasion, an effect that is blocked by addition of sFlt-1 (Zhou et al. 2002). In vivo evidence for this observation is lacking because normal invasion of trophoblast is relatively shallow even at baseline in rodents, compared to human placentas which show robust invasion. 
Other signaling systems involved in vessel maturation are PDGF and its receptor (PDGFR- $\beta$ ) and TGF- $\beta$ superfamily (Carmeliet 2003; Jain 2003). PDGF has essential roles in the stabilization of nascent blood vessels by recruiting PDGFR- $\beta$-positive mesenchymal progenitors. PDGF and its receptor have been shown to be present in the human placental vasculature (Holmgren et al. 1991). Null mutant placentas for Pdgfb and Pdgfrb show reduced numbers of pericytes, reduced fetal vessel density, and increased vessel diameter (Ohlsson et al. 1999). An activating mutation of Pdgfrb caused a disorganization of the fetal blood vessel compartment of the labyrinth (Looman et al. 2007). Taken together, these results suggest that PDGF and its receptor may also be important in placental vessel maturation. TGF- $\beta$ has shown to be expressed by trophoblasts along pregnancy (Xuan et al. 2007). Knockout models of TGF- $\beta$ family members show abnormal vessel development and many are embryonic lethal (Pardali et al. 2010). Although abnormalities in placental vasculature have been reported (Larsson et al. 2001; Hong et al. 2007), the mechanisms of TGF- $\beta$ family members' regulation of human placental vascular development remain to be elucidated.

Interestingly, pregnancy-specific growth factors and hormones, such as human chorionic gonadotropin (Zygmunt et al. 2002) and alphafetoprotein (Liang et al. 2004), and insulin-like growth factor-II (IGF-II) (Herr et al. 2003) have been shown to be proangiogenic, and therefore may also play a role in placental vascular development.

In summary, angiogenic factors are important not only for placental vascular development but also for other aspects of placentation such as regulation of trophoblast growth and differentiation. It is interesting to note that vessel formation may regulate placental development and vice versa through a number of different signaling systems. In this regard, studies in mice indicate that there is a complex interplay between the trophoblast and the development of its associated fetal-derived vasculature (Rossant and Cross 2001).

The characterization of antiangiogenic proteins in the placenta, in contrast to pro- angiogenic proteins, appears to have received far less attention. An important anti-angiogenic protein produced by the placenta that has recently been extensively studied is sFlt-1, an endogenous inhibitor of VEGF which, together with soluble endoglin (sEng), an endogenous inhibitor of TGF- $\beta$, have been shown to play an important role in the pathogenesis of preeclampsia Other anti-angiogenic proteins expressed in the placenta include thrombospondin-1, endostatin, and prolactin fragments; however, their role in placentation is unclear (Bdolah et al. 2004). Human placenta is thus a rich source of angiogenic substances and these may play an important role not only in the regulation of placental vessel formation but also, when released to the circulation, play a role in maternal vascular adaptation to pregnancy.

\section{PREECLAMPSIA}

Preeclampsia is a multisystem disease, characterized by new-onset hypertension and proteinuria after 20 weeks of gestation, which complicates $3 \%-8 \%$ of pregnancies (Duley 2009). It is a leading cause of maternal and perinatal morbidity and mortality worldwide (Duley 2009). In the mother, the disease can progress to widespread endothelial dysfunction affecting mainly the liver, the brain, and the kidney. Preeclampsia is also frequently associated with IUGR and prematurity (Sibai et al. 2005). As of 2011 treatment is supportive and the only known cure is delivery of the placenta.

The observation that this syndrome occurs solely in the presence of placental tissue (i.e., in pregnancy or with hydatidiform mole) (Shembrey and Noble 1995; Soto-Wright et al. 1995) and remits dramatically in the postpartum period after the placenta is delivered suggest that the placenta is both necessary and sufficient for the development of preeclampsia. Naturally, research focused on the placenta as the source of the disease. It has been proposed that preeclampsia is caused by placental dysfunction followed by the release of factors by the diseased placenta into the maternal circulation inducing endothelial dysfunction, which 
Angiogenic Factors in Preeclampsia

heralds the classical manifestations of the disease (Fig. 3).

The major pathological abnormality in the preeclamptic placenta is insufficient maternal spiral artery remodeling. Cytotrophoblast cells fail to acquire the endothelial-like phenotype and are unable to invade the myometrial spiral arteries. As a result, the myometrial segments remain narrow (Zhou et al. 1997a; Naicker et al. 2003; Kadyrov et al. 2006). The histological and physiological characteristics of these vessels do not change, they retain their original endothelial linings and muscular walls remaining high resistance vessels (Fig. 2) (Lin et al. 1995; Khaw et al. 2008). It has been theorized that this failure of conversion of spiral arteries

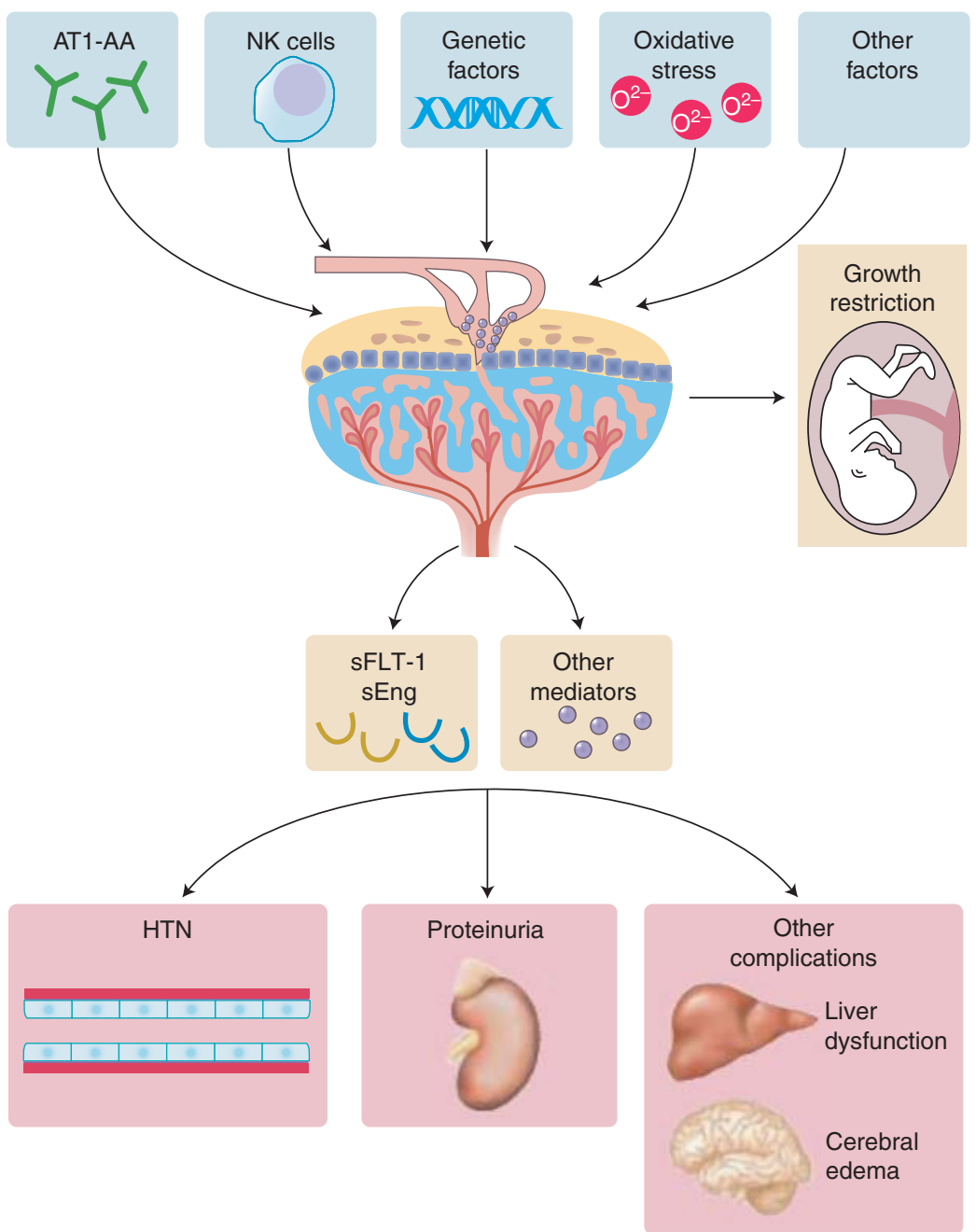

Figure 3. Summary of the pathogenesis of preeclampsia. Immune factors such as autoantibodies against the angiotensin receptor (AT1-AA), oxidative stress, natural killer (NK) cell abnormalities, and other factors may cause placental dysfunction, which in turn leads to the release of antiangiogenic factors (such as sFlt-1 and sEng) and other inflammatory mediators to induce hypertension (HTN), proteinuria, and other complications of preeclampsia. (Adapted from Wang et al. 2009; reprinted, with permission, from The American Physiological Society (C) 2009.) 
results in persistent placental hypoxia and dysfunction. However, it should be noted that placental hypoxia/ischemia alone may not be sufficient to produce preeclampsia because it is detected in many instances of IUGR in women without preeclampsia, and it should also be noted that histological evidence of spiral artery remodeling may be absent in some cases of preeclampsia. Thus other factors may concur to cause placental dysfunction. Various pathways including deficient heme oxygenase expression, genetic factors, oxidative stress, inflammation, altered natural killer cell signaling, and, more recently, deficient catechol$O$-methyl transferase (Redman and Sargent 2005; Cudmore et al. 2007; Kopcow and Karumanchi 2007; Kanasaki et al. 2008; Zhao et al. 2009) have been also proposed to have key roles in inducing placental disease (Fig. 3).

The role of maternal endothelial dysfunction in producing the clinical manifestations of preeclampsia has been studied extensively since the 1980s (Roberts et al. 1989; Ferris 1991) and extensive data support the notion that the maternal serum in preeclampsia has soluble factors which mediate endothelial dysfunction. The search for these factors led to the characterization of soluble Fms-like tyrosine kinase 1 (sFlt-1), an antiangiogenic protein that is overproduced by the placenta and induces systemic endothelial dysfunction.

In 2003 it was shown that placental expression of sFlt-1 is strikingly increased in preeclampsia and this is associated with increased levels of maternal circulating sFlt-1 and decreased levels of free bioactive VEGF and PlGF (Maynard et al. 2003), a finding that has been confirmed by several groups (Buhimschi et al. 2005; Levine et al. 2005; Aggarwal et al. 2006). It was also observed that serum from patients with preeclampsia inhibited endothelial tube formation in vitro and that 48 hours postpartum, this antiangiogenic effect had disappeared from the serum. Moreover, when injected into pregnant rats, sFlt-1 induced hypertension, proteinuria, and glomerular endotheliosis, the hallmarks of the disease (Maynard et al. 2003). Circulating levels of sFlt-1 begin to rise before the onset of clinical symptoms (Levine et al. 2004) and correlate with the severity of the disease (Chaiworapongsa et al. 2004), suggesting important diagnostic and predictive potential (Cerdeira and Karumanchi 2010). Several risk factors for preeclampsia can also be correlated with increased sFlt-1 such as multigestational pregnancies (Bdolah et al. 2008; Maynard et al. 2008), hydatidiform mole (Koga et al. 2010), trisomy 13 (Bdolah et al. 2006), and nulliparity (Wolf et al. 2005). Potential additional contributors as a source of sFlt- 1 besides trophoblasts include peripheral blood mononuclear cells (Rajakumar et al. 2005) and proteolytic shedding of extracellular fragment of Flt-1 in endothelial cells (Rahimi et al. 2009; Zhao et al. 2010), but the clinical significance of these sources is unknown.

Placental syncytiotrophoblasts and in particular syncytial knots were identified as a major source of sFlt-1 production (Sela et al. 2008). Syncytial knots are induced by placental hypoxia and are noted predominantly in preeclamptic placentas. Interestingly syncytial knots and placental debris have been shown to be released into the maternal circulation suggesting an additional source of increased sFlt-1 in the maternal blood besides secretion by the placenta (Lok et al. 2008). Much work has been done regarding placental hypoxia and its possible role in preeclampsia. It has been shown to increase sFlt-1 expression. Many other factors have also been shown to increase placental production of sFlt-1 such as angiotensin II and autoantibodies against angiotensin receptor-1 (Zhou et al. 2007). Furthermore, several animal models of preeclampsia show an increase in sFlt-1, suggesting that this molecule may be a central culprit in the pathogenesis of preeclampsia which originates with different insults to the placenta converging on a final common pathway mediated by excess release of sFlt-1 into the maternal circulation.

The other two VEGF receptors (KDR and Flt-4) are also expressed in human placentas; Flt-4 expression has been shown to remain unchanged (Helske et al. 2001) and KDR has been shown to be not changed (Helske et al. 2001) or reduced (Tripathi et al. 2009; Groten 
Angiogenic Factors in Preeclampsia

et al. 2010). A soluble form of human KDR was described (Ebos et al. 2004), and appears to be decreased in preeclampsia (Chaiworapongsa et al. 2010); however, its role in preeclampsia is unknown.

There is circumstantial evidence that antagonism of VEGF and PlGF may have a pathogenic role in the appearance of hypertension and proteinuria. VEGF stabilizes endothelial cells in mature blood vessels and is particularly important in maintaining the health of the endothelium in the kidney, liver, and brain (Esser et al. 1998). VEGF induces nitric oxide and vasodilatory prostacyclins in endothelial cells suggesting a physiological role in decreasing vascular tone and blood pressure (He et al. 1999). A 50\% reduction of glomerular VEGF leads to glomerular endotheliosis and proteinuria similar to that seen in preeclampsia (Eremina et al. 2003) and VEGF has been shown to ameliorate cyclosporine-related hypertension, endothelial dysfunction, and nephropathy (Kang et al. 2001). Moreover, cancer patients receiving VEGF inhibitors therapeutically present hypertension and proteinuria along with glomerular damage as adverse effects that resembling preeclampsia (Zhu et al. 2007; Patel et al. 2008). Collectively these data suggest that VEGF is important not only in blood pressure regulation but also in maintaining the glomerular filtration barrier. Thus antagonism of VEGF signaling, such as with an excess of sFlt-1, may lead to endothelial dysfunction, proteinuria, and hypertension.

It is likely that other factors elaborated by the placenta act synergistically with sFlt-1. This is supported by the observation that while overexpression of sFlt-1 in rats reproduced the hallmarks of the disease, the severe phenotype was not reproduced. The search for additional factors identified soluble endoglin (sEng) as another antiangiogenic molecule deregulated in preeclampsia.

sEng is a truncated form of endoglin generated by shedding of the extracellular domain. Endoglin is a co-receptor for transforming growth factor (TGF) $\beta 1$ and 3 (Cheifetz et al. 1992) and is highly expressed on cell membranes of vascular endothelium and syncytiotrophoblasts (Gougos et al. 1992). sEng interferes with TGF- $\beta$ signaling and eNOS activation and thereby causes endothelial dysfunction (Toporsian et al. 2005; Venkatesha et al. 2006). When overexpressed by adenoviral vector in rats, sEng causes proteinuria and hypertension that are milder then seen with sFlt-1 overexpression alone. However, when sEng is co-expressed with sFlt-1, the rats develop severe proteinuria, hypertension, and IUGR of the pups, as well as hemolysis, elevated liver enzymes, and low platelets similar to the HELLP syndrome. Placental endoglin is upregulated in preeclampsia, releasing sEng to the maternal circulation (Venkatesha et al. 2006). Clinically, it was shown to be increased in the sera of preeclamptic women 2-3 months before the onset of the clinical signs of preeclampsia and to correlate with disease severity (Levine et al. 2006). Several unanswered questions remain related to the role of sFlt- 1 and sEng in the pathogenesis of preeclampsia. The exact role of sFlt- 1 and sEng in normal placental development and in placental pseudovasculogenesis is not clear.

\section{Angiogenesis and the Remote History of Preeclampsia}

Considerable evidence suggests that preeclampsia predisposes women to late cardiac and vascular diseases (Funai et al. 2005; Irgens et al. 2001). Whether preeclampsia per se is a cause of future hypertension at heart disease, or if this represents the sequestration of women predestined to these disorders into the preeclamptic population remains unknown. Recent study of cardiovascular risk factors present before and after pregnancy suggests that nearly half of the elevated risk for future hypertension after preeclampsia can be explained by prepregnancy risk factors (Romundstad et al. 2010). Therefore, pregnancy may be viewed as a stress test that can reveal subclinical cardiovascular disease phenotypes long before overt disease. It is also tempting to speculate that the long-term cardiovascular complications noted in some patients who have had preeclampsia may be due to a chronic antiangiogenic state resulting 
from polymorphisms in genes such as sFlt-1. Additionally, patients with preeclampsia are said to have a decreased long-term incidence of malignancy (Vatten et al. 2002), a provocative observation disputed by some (Mogren et al. 2001), which may suggest that the antiangiogenic state of preeclampsia may reflect a more permanent maternal milieu.

\section{INTRAUTERINE GROWTH RESTRICTION}

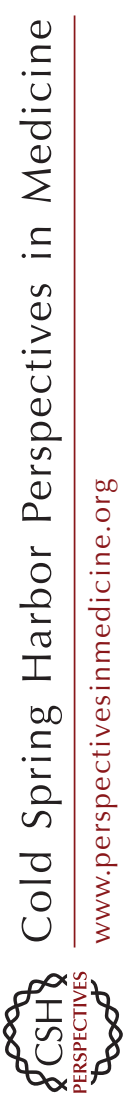

Normal fetal growth is a complex interplay of fetal, maternal, and placental health. An abnormality in any of these three systems leads to small for gestational age (SGA) babies. SGA babies that arise as a result of placental vascular insufficiency are referred to as IUGR. Although IUGR is frequently associated with severe premature preeclampsia, IUGR can also occur in the absence of any evidence of preeclampsia. Low birth weight in IUGR babies has also been suggested as a predisposing factor for increased hypertension and cardiovascular diseases later in life (Baschat and Hecher 2004). Normal pregnancy results in a significant increase in diastolic blood flow velocity as a result of physiological maternal vascular remodeling. In pregnancies complicated by IUGR there is severe placental vascular insufficiency and the Doppler waveforms are similar to the nonpregnant state (Harrington et al. 1996). This can be shown by several methods including Doppler ultrasound and MRI imaging of the uterine vessels. Similar to preeclampsia, placental bed biopsies in human IUGR show impaired migration of the extravillous trophoblasts and remodeling of the maternal spiral arterioles (Brosens et al. 1972). It is still unclear why some patients with IUGR have the full-blown maternal syndrome of preeclampsia, while others do not. Human IUGR placentas, but not preeclamptic placentas, have also been found to have defective villous capillarization (Mayhew et al. 2004). The morphology of the trophoblast covering these diseased villi are also abnormal with reduced amounts of proliferating villous cytotrophoblasts, and an apoptotic syncytiotrophoblast. It is believed that less oxygen extraction and consumption by the IUGR fetus and the resulting higher levels of $\mathrm{pO}_{2}$ have been hypothesized to inhibit the fetoplacental angiogenesis (Chaddha et al. 2004). However, studies documenting lack of relative hypoxia in IUGR placentas (without preeclampsia) are still lacking. Impairment of insulin-like growth factor (IGF) I and II signaling pathways in experimental animals leads to IUGR (DeChiara et al. 1990; Baker et al. 1993; Crossey et al. 2002). Two babies with IUGR were reported to have mutations of the IGF-1R gene (Abuzzahab et al. 2003). Although abnormalities in IGF signaling are a relatively uncommon cause of IUGR, impaired IGF-II signaling through IGF1R is the first molecular abnormality that has been reported in this complex disease. IGFs are potent proangiogenic molecules both in vitro and in vivo (Herr et al. 2003; Lopez-Lopez et al. 2004; Rabinovsky and Draghia-Akli 2004). Abnormalities in other angiogenic proteins have been shown in small clinical studies, but definitive pathogenic roles for these factors have not been demonstrated so far. Serum concentrations of sFlt-1 have been found to be increased modestly in patients with intrauterine growth retardation without preeclampsia (Tsatsaris et al. 2003), a finding that has not been confirmed by others (Shibata et al. 2005). Endostatin concentrations in the fetus and neonate were reported to be lower in pregnancies complicated by IUGR (Malamitsi-Puchner et al. 2005). Leptin and asymmetric dimethylarginine have also been reported to be elevated during placental insufficiency (Lepercq et al. 2003; Savvidou et al. 2003), but the cause-and-effect relationship of these molecules has not yet been established.

\section{CONCLUSIONS}

Normal placental development is characterized by vasculogenesis, angiogenesis, and pseudovasculogenesis, which are tightly regulated by a balance between pro- and antiangiogenic factors. Abnormalities in this regulation may lead to adverse obstetric outcomes such as preeclampsia and IUGR and also compromise adult health. Preeclampsia is characterized by 
an increased placental production of antiangiogenic molecules such as sFlt-1 and sEng which are implicated in the pathogenesis of the disease. Several recent clinical studies suggest that angiogenic biomarkers such as sFlt-1 and PLGF may serve to diagnose and predict preeclampsia and its related complications. In addition, depleting or antagonizing sFlt-1 and sEng in the maternal circulation may prove to be a valuable approach for preeclampsia treatment. Understanding the mechanisms that regulate placental vascular development might allow the development of new preventive strategies for pregnancy complications.

\section{REFERENCES}

Abuzzahab MJ, Schneider A, Goddard A, Grigorescu F, Lautier C, Keller E, Kiess W, Klammt J, Kratzsch J, Osgood D, et al. 2003. IGF-I receptor mutations resulting in intrauterine and postnatal growth retardation. $\mathrm{NEngl} \mathrm{J}$ Med 349: 2211-2222.

Aggarwal PK, Jain V, Sakhuja V, Karumanchi SA, Jha V. 2006. Low urinary placental growth factor is a marker of pre-eclampsia. Kidney Int 69: 621-624.

Baker J, Liu JP, Robertson EJ, Efstratiadis A. 1993. Role of insulin-like growth factors in embryonic and postnatal growth. Cell 75: 73-82.

Barker DJ. 2003. The developmental origins of adult disease. Eur J Epidemiol 18: 733-736.

Baschat AA, Hecher K. 2004. Fetal growth restriction due to placental disease. Semin Perinatol 28: 67-80.

Bdolah Y, Sukhatme VP, Karumanchi SA. 2004. Angiogenic imbalance in the pathophysiology of preeclampsia: Newer insights. Semin Nephrol 24: 548-556.

Bdolah Y, Palomaki GE, Yaron Y, Bdolah-Abram T, Goldman M, Levine RJ, Sachs BP, Haddow JE, Karumanchi SA. 2006. Circulating angiogenic proteins in trisomy 13. Am J Obstet Gynecol 194: 239-245.

Bdolah Y, Lam C, Rajakumar A, Shivalingappa V, Mutter W, Sachs BP, Lim KH, Bdolah-Abram T, Epstein FH, Karumanchi SA. 2008. Twin pregnancy and the risk of preeclampsia: Bigger placenta or relative ischemia? Am J Obstet Gynecol 198: 428 e421-e426.

Bjorndahl M, Cao R, Eriksson A, Cao Y. 2004. Blockage of VEGF-induced angiogenesis by preventing VEGF secretion. Circ Res 94: 1443-1450.

Brosens IA, Robertson WB, Dixon HG. 1972. The role of the spiral arteries in the pathogenesis of preeclampsia. Obstet Gynecol Annu 1: 177-191.

Buhimschi CS, Norwitz ER, Funai E, Richman S, Guller S, Lockwood CJ, Buhimschi IA. 2005. Urinary angiogenic factors cluster hypertensive disorders and identify women with severe preeclampsia. Am J Obstet Gynecol 192: $734-741$.
Carmeliet P. 2003. Angiogenesis in health and disease. Nat Med 9: 653-660.

Carmeliet P, Moons L, Luttun A, Vincenti V, Compernolle V, De Mol M, Wu Y, Bono F, Devy L, Beck H, et al. 2001. Synergism between vascular endothelial growth factor and placental growth factor contributes to angiogenesis and plasma extravasation in pathological conditions. Nat Med 7: 575-583.

Carmeliet P, De Smet F, Loges S, Mazzone M. 2009. Branching morphogenesis and antiangiogenesis candidates: Tip cells lead the way. Nat Rev Clin Oncol 6: 315-326.

Castellucci M, Kosanke G, Verdenelli F, Huppertz B, Kaufmann P. 2000. Villous sprouting: Fundamental mechanisms of human placental development. Hum Reprod Update 6: 485-494.

Cerdeira AS, Karumanchi SA. 2010. Angiogenic proteins as aid in the diagnosis and prediction of preeclampsia. Scand J Clin Lab Invest Suppl 242: 73-78.

Chaddha V, Viero S, Huppertz B, Kingdom J. 2004. Developmental biology of the placenta and the origins of placental insufficiency. Semin Fetal Neonatal Med 9: 357-369.

Chaiworapongsa T, Romero R, Espinoza J, Bujold E, Mee Kim Y, Goncalves LF, Gomez R, Edwin S. 2004. Evidence supporting a role for blockade of the vascular endothelial growth factor system in the pathophysiology of preeclampsia. Young Investigator Award. Am J Obstet Gynecol 190: 1541-1547; discussion 1547-1550.

Chaiworapongsa T, Romero R, Tarca AL, Kusanovic JP, Gotsch F, Mittal P, Kim SK, Vaisbuch E, Mazaki-Tovi S, Erez O, et al. 2010. A decrease in maternal plasma concentrations of sVEGFR-2 precedes the clinical diagnosis of preeclampsia. Am J Obstet Gynecol 202: 550.e1-550.e10.

Chappell JC, Taylor SM, Ferrara N, Bautch VL. 2009. Local guidance of emerging vessel sprouts requires soluble Flt-1. Dev Cell 17: 377-386.

Charnock-Jones DS, Sharkey AM, Boocock CA, Ahmed A, Plevin R, Ferrara N, Smith SK. 1994. Vascular endothelial growth factor receptor localization and activation in human trophoblast and choriocarcinoma cells. Biol Reprod 51: 524-530.

Cheifetz S, Bellon T, Cales C, Vera S, Bernabeu C, Massague J, Letarte M. 1992. Endoglin is a component of the transforming growth factor-beta receptor system in human endothelial cells. J Biol Chem 267: 19027-19030.

Clark DE, Smith SK, Sharkey AM, Charnock-Jones DS. 1996. Localization of VEGF and expression of its receptors flt and KDR in human placenta throughout pregnancy. Hum Reprod 11: 1090-1098.

Clark DE, Smith SK, Licence D, Evans AL, Charnock-Jones DS. 1998. Comparison of expression patterns for placenta growth factor, vascular endothelial growth factor (VEGF), VEGF-B and VEGF-C in the human placenta throughout gestation. J Endocrinol 159: 459-467.

Cooper JC, Sharkey AM, McLaren J, Charnock-Jones DS, Smith SK. 1995. Localization of vascular endothelial growth factor and its receptor, flt, in human placenta and decidua by immunohistochemistry. J Reprod Fertil 105: 205-213.

Cross JC, Werb Z, Fisher SJ. 1994. Implantation and the placenta: Key pieces of the development puzzle. Science 266: 1508-1518. 
Crossey PA, Pillai CC, Miell JP. 2002. Altered placental development and intrauterine growth restriction in IGF binding protein-1 transgenic mice. JClin Invest 110: 411-418.

Cudmore M, Ahmad S, Al-Ani B, Fujisawa T, Coxall H, Chudasama K, Devey LR, Wigmore SJ, Abbas A, Hewett PW, et al. 2007. Negative regulation of soluble Flt-1 and soluble endoglin release by heme oxygenase-1. Circulation 115: 1789-1797.

de Rooij SR, Wouters H, Yonker JE, Painter RC, Roseboom TJ. 2010. Prenatal undernutrition and cognitive function in late adulthood. Proc Natl Acad Sci 107: 16881-16886.

De Wolf F, Wolf-Peeters CDe, Brosens I, Robertson WB. 1980. The human placental bed: Electron microscopic study of trophoblastic invasion of spiral arteries. Am J Obstet Gynecol 137: 58-70.

DeChiara TM, Efstratiadis A, Robertson EJ. 1990. A growthdeficiency phenotype in heterozygous mice carrying an insulin-like growth factor II gene disrupted by targeting. Nature 345: 78-80.

Demir R. 2009. Expression of VEGF receptors VEFGR-1 and VEGFR-2, angiopoietin receptors Tie-1 and Tie-2 in chorionic villi tree during early pregnancy. Folia Histochem Cytobiol 47: 435-445.

Demir R, Kaufmann P, Castellucci M, Erbengi T, Kotowski A. 1989. Fetal vasculogenesis and angiogenesis in human placental villi. Acta Anat (Basel) 136: 190-203.

Demir R, Kayisli UA, Seval Y, Celik-Ozenci C, Korgun ET, Demir-Weusten AY, Huppertz B. 2004. Sequential expression of VEGF and its receptors in human placental villi during very early pregnancy: Differences between placental vasculogenesis and angiogenesis. Placenta 25: $560-572$.

Duley L. 2009. The global impact of pre-eclampsia and eclampsia. Semin Perinatol 33: 130-137.

Dunk C, Shams M, Nijjar S, Rhaman M, Qiu Y, Bussolati B, Ahmed A. 2000. Angiopoietin-1 and angiopoietin-2 activate trophoblast Tie-2 to promote growth and migration during placental development. Am J Pathol 156: $2185-$ 2199.

Dvorak HF. 2002. Vascular permeability factor/vascular endothelial growth factor: A critical cytokine in tumor angiogenesis and a potential target for diagnosis and therapy. J Clin Oncol 20: 4368-4380.

Ebos JM, Bocci G, Man S, Thorpe PE, Hicklin DJ, Zhou D, Jia X, Kerbel RS. 2004. A naturally occurring soluble form of vascular endothelial growth factor receptor 2 detected in mouse and human plasma. Mol Cancer Res 2: 315-326.

Eremina V, Sood M, Haigh J, Nagy A, Lajoie G, Ferrara N, Gerber HP, Kikkawa Y, Miner JH, Quaggin SE. 2003. Glomerular-specific alterations of VEGF-A expression lead to distinct congenital and acquired renal diseases. J Clin Invest 111: 707-716.

Esser S, Wolburg K, Wolburg H, Breier G, Kurzchalia T, Risau W. 1998. Vascular endothelial growth factor induces endothelial fenestrations in vitro. J Cell Biol 140: 947-959.

Ferris TF. 1991. Pregnancy, preeclampsia, and the endothelial cell. N Engl J Med 325: 1439-1440.
Fischer C, Mazzone M, Jonckx B, Carmeliet P. 2008. FLT1 and its ligands VEGFB and PIGF: Drug targets for antiangiogenic therapy? Nat Rev Cancer 8: 942-956.

Folkman J, Shing Y. 1992. Angiogenesis. J Biol Chem 267: 10931-10934.

Funai EF, Friedlander Y, Paltiel O, Tiram E, Xue X, Deutsch L, Harlap S. 2005. Long-term mortality after preeclampsia. Epidemiology 16: 206-215.

Genbacev O, Zhou Y, Ludlow JW, Fisher SJ. 1997. Regulation of human placental development by oxygen tension. Science 277: 1669-1672.

Geva E, Ginzinger DG, Zaloudek CJ, Moore DH, Byrne A, Jaffe RB. 2002. Human placental vascular development Vasculogenic and angiogenic (branching and nonbranching) transformation is regulated by vascular endothelial growth factor-A, angiopoietin-1, and angiopoietin-2. J Clin Endocrinol Metab 87: 4213-4224.

Goldman-Wohl DS, Ariel I, Greenfield C, Lavy Y, Yagel S. 2000. Tie-2 and angiopoietin-2 expression at the fetalmaternal interface: A receptor ligand model for vascular remodelling. Mol Hum Reprod 6: 81-87.

Gougos A, St Jacques S, Greaves A, O'Connell PJ, d'Apice AJ, Buhring HJ, Bernabeu C, Mourik JAvan, Letarte M. 1992. Identification of distinct epitopes of endoglin, an RGDcontaining glycoprotein of endothelial cells, leukemic cells, and syncytiotrophoblasts. Int Immunol 4: 83-92.

Groten T, Gebhard N, Kreienberg R, Schleussner E, Reister F, Huppertz B. 2010. Differential expression of VE-cadherin and VEGFR2 in placental syncytiotrophoblast during preeclampsia-New perspectives to explain the pathophysiology. Placenta 31: 339-343.

Hanna J, Goldman-Wohl D, Hamani Y, Avraham I, Greenfield C, Natanson-Yaron S, Prus D, Cohen-Daniel L, Arnon TI, Manaster I, et al. 2006. Decidual NK cells regulate key developmental processes at the human fetal-maternal interface. Nat Med 12: 1065-1074.

Harrington K, Cooper D, Lees C, Hecher K, Campbell S. 1996. Doppler ultrasound of the uterine arteries: The importance of bilateral notching in the prediction of pre-eclampsia, placental abruption or delivery of a small-for-gestational-age baby. Ultrasound Obstet Gynecol 7: $182-188$.

Hashizume H, Falcon BL, Kuroda T, Baluk P, Coxon A, Yu D, Bready JV, Oliner JD, McDonald DM. 2010. Complementary actions of inhibitors of angiopoietin-2 and VEGF on tumor angiogenesis and growth. Cancer Res 70: $2213-2223$.

He H, Venema VJ, Gu X, Venema RC, Marrero MB, Caldwell RB. 1999. Vascular endothelial growth factor signals endothelial cell production of nitric oxide and prostacyclin through flk-1/KDR activation of c-Src. J Biol Chem 274: 25130-25135.

Helske S, Vuorela P, Carpen O, Hornig C, Weich H, Halmesmaki E. 2001. Expression of vascular endothelial growth factor receptors 1, 2 and 3 in placentas from normal and complicated pregnancies. Mol Hum Reprod 7: 205-210.

Herr F, Liang OD, Herrero J, Lang U, Preissner KT, Han VK, Zygmunt M. 2003. Possible angiogenic roles of insulinlike growth factor II and its receptors in uterine vascular adaptation to pregnancy. J Clin Endocrinol Metab 88: 4811-4817. 
Holmgren L, Glaser A, Pfeifer-Ohlsson S, Ohlsson R. 1991. Angiogenesis during human extraembryonic development involves the spatiotemporal control of PDGF ligand and receptor gene expression. Development 113: 749 754.

Hong KH, Seki T, Oh SP. 2007. Activin receptor-like kinase 1 is essential for placental vascular development in mice. Lab Invest 87: 670-679.

Huckle WR, Roche RI. 2004. Post-transcriptional control of expression of sFlt-1, an endogenous inhibitor of vascular endothelial growth factor. J Cell Biochem 93: 120-132.

Huppertz B. 2008. The anatomy of the normal placenta. J Clin Pathol 61: 1296-1302.

Irgens HU, Reisaeter L, Irgens LM, Lie RT. 2001. Long term mortality of mothers and fathers after pre-eclampsia: Population based cohort study. Br Med J323: 1213-1217.

Irving RJ, Belton NR, Elton RA, Walker BR. 2000. Adult cardiovascular risk factors in premature babies. Lancet 355: 2135-2136.

Jain RK. 2003. Molecular regulation of vessel maturation. Nat Med 9: 685-693.

James JL, Stone PR, Chamley LW. 2006. The regulation of trophoblast differentiation by oxygen in the first trimester of pregnancy. Hum Reprod Update 12: 137-144.

Jirkovska M, Janacek J, Kalab J, Kubinova L. 2008. Threedimensional arrangement of the capillary bed and its relationship to microrheology in the terminal villi of normal term placenta. Placenta 29: 892-897.

Kadyrov M, Kingdom JC, Huppertz B. 2006. Divergent trophoblast invasion and apoptosis in placental bed spiral arteries from pregnancies complicated by maternal anemia and early-onset preeclampsia/intrauterine growth restriction. Am J Obstet Gynecol 194: 557-563.

Kanasaki K, Palmsten K, Sugimoto H, Ahmad S, Hamano Y, Xie L, Parry S, Augustin HG, Gattone VH, Folkman J, et al. 2008. Deficiency in catechol-O-methyltransferase and 2-methoxyoestradiol is associated with preeclampsia. Nature 453: 1117-1121.

Kang DH, Kim YG, Andoh TF, Gordon KL, Suga S, Mazzali M, Jefferson JA, Hughes J, Bennett W, Schreiner GF, et al. 2001. Post-cyclosporine-mediated hypertension and nephropathy: Amelioration by vascular endothelial growth factor. Am J Physiol Renal Physiol 280: F727F736.

Kaufmann P, Bruns U, Leiser R, Luckhardt M, Winterhager E. 1985. The fetal vascularisation of term human placental villi. II. Intermediate and terminal villi. Anat Embryol 173: $203-214$.

Kaufmann P, Luckhardt M, Schweikhart G, Cantle SJ. 1987. Cross-sectional features and three-dimensional structure of human placental villi. Placenta 8: 235-247.

Kaufmann P, Mayhew TM, Charnock-Jones DS. 2004. Aspects of human fetoplacental vasculogenesis and angiogenesis. II. Changes during normal pregnancy. Placenta 25: 114-126.

Kayisli UA, Cayli S, Seval Y, Tertemiz F, Huppertz B, Demir R. 2006. Spatial and temporal distribution of Tie-1 and Tie-2 during very early development of the human placenta. Placenta 27: 648-659.

Kearney JB, Kappas NC, Ellerstrom C, DiPaola FW, Bautch VL. 2004. The VEGF receptor flt-1 (VEGFR-1) is a positive modulator of vascular sprout formation and branching morphogenesis. Blood 103: 4527-4535.

Kendall RL, Thomas KA. 1993. Inhibition of vascular endothelial cell growth factor activity by an endogenously encoded soluble receptor. Proc Natl Acad Sci 90: 10705-10709.

Khaw A, Kametas NA, Turan OM, Bamfo JE, Nicolaides KH. 2008. Maternal cardiac function and uterine artery Doppler at 11-14 weeks in the prediction of pre-eclampsia in nulliparous women. BJOG 115: 369-376.

Koga K, Osuga Y, Tajima T, Hirota Y, Igarashi T, Fujii T, Yano T, Taketani Y. 2010. Elevated serum soluble fms-like tyrosine kinase 1 (sFlt1) level in women with hydatidiform mole. Fertil Steril 94: 305-308.

Kohnen G, Kertschanska S, Demir R, Kaufmann P. 1996. Placental villous stroma as a model system for myofibroblast differentiation. Histochem Cell Biol 105: 415-429.

Kopcow HD, Karumanchi SA. 2007. Angiogenic factors and natural killer (NK) cells in the pathogenesis of preeclampsia. J Reprod Immunol 76: 23-29.

Kumazaki K, Nakayama M, Suehara N, Wada Y. 2002. Expression of vascular endothelial growth factor, placental growth factor, and their receptors Flt-1 and KDR in human placenta under pathologic conditions. Hum Pathol 33: 1069-1077.

Lam C, Lim KH, Karumanchi SA. 2005. Circulating angiogenic factors in the pathogenesis and prediction of preeclampsia. Hypertension 46: 1077-1085.

Larsson J, Goumans MJ, Sjostrand LJ, van Rooijen MA, Ward D, Leveen P, Xu X, ten Dijke P, Mummery CL, Karlsson S. 2001. Abnormal angiogenesis but intact hematopoietic potential in TGF-beta type I receptor-deficient mice. EMBO J 20: 1663-1673.

Lash GE, Naruse K, Innes BA, Robson SC, Searle RF, Bulmer JN. 2010. Secretion of angiogenic growth factors by villous cytotrophoblast and extravillous trophoblast in early human pregnancy. Placenta 31: 545-548.

Lepercq J, Guerre-Millo M, Andre J, Cauzac M, Hauguel-de Mouzon S. 2003. Leptin: A potential marker of placental insufficiency. Gynecol Obstet Invest 55: 151-155.

Levine RJ, Maynard SE, Qian C, Lim KH, England LJ, Yu KF, Schisterman EF, Thadhani R, Sachs BP, Epstein FH, et al. 2004. Circulating angiogenic factors and the risk of preeclampsia. $N$ Engl J Med 350: 672-683.

Levine RJ, Thadhani R, Qian C, Lam C, Lim KH, Yu KF, Blink AL, Sachs BP, Epstein FH, Sibai BM, et al. 2005. Urinary placental growth factor and risk of preeclampsia. J Am Med Assoc 293: 77-85.

Levine RJ, Lam C, Qian C, Yu KF, Maynard SE, Sachs BP, Sibai BM, Epstein FH, Romero R, Thadhani R, et al. 2006. Soluble endoglin and other circulating antiangiogenic factors in preeclampsia. $N$ Engl J Med 355: 992-1005

Liang OD, Korff T, Eckhardt J, Rifaat J, Baal N, Herr F, Preissner KT, Zygmunt M. 2004. Oncodevelopmental alpha-fetoprotein acts as a selective proangiogenic factor on endothelial cell from the fetomaternal unit. J Clin Endocrinol Metab 89: 1415-1422.

Lin S, Shimizu I, Suehara N, Nakayama M, Aono T. 1995. Uterine artery Doppler velocimetry in relation to 
A.S. Cerdeira and S.A. Karumanchi

trophoblast migration into the myometrium of the placental bed. Obstet Gynecol 85: 760-765.

Lok CA, Boing AN, Sargent IL, Sooranna SR, van der Post JA, Nieuwland R, Sturk A. 2008. Circulating plateletderived and placenta-derived microparticles expose Flt-1 in preeclampsia. Reprod Sci 15: 1002-1010.

Looman C, Sun T, Yu Y, Zieba A, Ahgren A, Feinstein R, Forsberg H, Hellberg C, Heldin CH, Zhang XQ, et al. 2007. An activating mutation in the PDGF receptor-beta causes abnormal morphology in the mouse placenta. Int J Dev Biol 51: 361-370.

Lopez-Lopez C, LeRoith D, Torres-Aleman I. 2004. Insulinlike growth factor I is required for vessel remodeling in the adult brain. Proc Natl Acad Sci 101: 9833-9838.

Macara L, Kingdom JC, Kaufmann P, Kohnen G, Hair J, More IA, Lyall F, Greer IA. 1996. Structural analysis of placental terminal villi from growth-restricted pregnancies with abnormal umbilical artery Doppler waveforms. Placenta 17: 37-48.

Malamitsi-Puchner A, Boutsikou T, Economou E, Makrakis E, Iliodromiti Z, Kouskouni E, Hassiakos D. 2005. The role of the anti-angiogenic factor endostatin in intrauterine growth restriction. J Soc Gynecol Investig 12: 195-197.

Mayhew TM, Wijesekara J, Baker PN, Ong SS. 2004. Morphometric evidence that villous development and fetoplacental angiogenesis are compromised by intrauterine growth restriction but not by pre-eclampsia. Placenta 25: 829-833.

Maynard SE, Min JY, Merchan J, Lim KH, Li J, Mondal S, Libermann TA, Morgan JP, Sellke FW, Stillman IE, et al. 2003. Excess placental soluble fms-like tyrosine kinase 1 (sFlt1) may contribute to endothelial dysfunction, hypertension, and proteinuria in preeclampsia. J Clin Invest 111: $649-658$.

Maynard SE, Simas TAMoore, Solitro MJ, Rajan A, Crawford S, Soderland P, Meyer BA. 2008. Circulating angiogenic factors in singleton vs multiple-gestation pregnancies. Am J Obstet Gynecol 198: 200 e201-e207.

Meegdes BH, Ingenhoes R, Peeters LL, Exalto N. 1988. Early pregnancy wastage: Relationship between chorionic vascularization and embryonic development. Fertil Steril 49: $216-220$.

Mogren I, Stenlund H, Hogberg U. 2001. Long-term impact of reproductive factors on the risk of cervical, endometrial, ovarian and breast cancer. Acta Oncol 40: 849-854.

Naicker T, Khedun SM, Moodley J, Pijnenborg R. 2003. Quantitative analysis of trophoblast invasion in preeclampsia. Acta Obstet Gynecol Scand 82: 722-729.

Ohlsson R, Falck P, Hellstrom M, Lindahl P, Bostrom H, Franklin G, Ahrlund-Richter L, Pollard J, Soriano P, Betsholtz C. 1999. PDGFB regulates the development of the labyrinthine layer of the mouse fetal placenta. Dev Biol 212: 124-136.

Osol G, Mandala M. 2009. Maternal uterine vascular remodeling during pregnancy. Physiology (Bethesda) 24: 58-71.

Pardali E, Goumans MJ, ten Dijke P. 2010. Signaling by members of the TGF-beta family in vascular morphogenesis and disease. Trends Cell Biol 20: 556-567.

Patel TV, Morgan JA, Demetri GD, George S, Maki RG, Quigley M, Humphreys BD. 2008. A preeclampsia-like syndrome characterized by reversible hypertension and proteinuria induced by the multitargeted kinase inhibitors sunitinib and sorafenib. J Natl Cancer Inst 100: 282-284.

Rabinovsky ED, Draghia-Akli R. 2004. Insulin-like growth factor I plasmid therapy promotes in vivo angiogenesis. Mol Ther 9: 46-55.

Rahimi N, Golde TE, Meyer RD. 2009. Identification of ligand-induced proteolytic cleavage and ectodomain shedding of VEGFR-1/FLT1 in leukemic cancer cells. Cancer Res 69: 2607-2614.

Rajakumar A, Michael HM, Rajakumar PA, Shibata E, Hubel CA, Karumanchi SA, Thadhani R, Wolf M, Harger G, Markovic N. 2005. Extra-placental expression of vascular endothelial growth factor receptor-1, (Flt-1) and soluble Flt-1 (sFlt-1), by peripheral blood mononuclear cells (PBMCs) in normotensive and preeclamptic pregnant women. Placenta 26: 563-573.

Redman CW, Sargent IL. 2005. Latest advances in understanding preeclampsia. Science 308: 1592-1594.

Roberts JM, Taylor RN, Musci TJ, Rodgers GM, Hubel CA, McLaughlin MK. 1989. Preeclampsia: An endothelial cell disorder. Am J Obstet Gynecol 161: 1200-1204.

Romundstad PR, Magnussen EB, Smith GD, Vatten LJ. 2010. Hypertension in pregnancy and later cardiovascular risk. Common antecedents? Circulation 122: 579-584.

Rossant J, Cross JC. 2001. Placental development: Lessons from mouse mutants. Nat Rev Genet 2: 538-548.

Savvidou MD, Hingorani AD, Tsikas D, Frolich JC, Vallance P, Nicolaides KH. 2003. Endothelial dysfunction and raised plasma concentrations of asymmetric dimethylarginine in pregnant women who subsequently develop pre-eclampsia. Lancet 361: 1511-1517.

Schulz LC. 2010. The Dutch Hunger Winter and the developmental origins of health and disease. Proc Natl Acad Sci 107: 16757-16758.

Sela S, Itin A, Natanson-Yaron S, Greenfield C, GoldmanWohl D, Yagel S, Keshet E. 2008. A novel human-specific soluble vascular endothelial growth factor receptor 1: Cell-type-specific splicing and implications to vascular endothelial growth factor homeostasis and preeclampsia. Circ Res 102: 1566-1574.

Seval Y, Sati L, Celik-Ozenci C, Taskin O, Demir R. 2008. The distribution of angiopoietin-1, angiopoietin-2 and their receptors tie- 1 and tie- 2 in the very early human placenta. Placenta 29: 809-815.

Shembrey MA, Noble AD. 1995. An instructive case of abdominal pregnancy. Aust NZ J Obstet Gynaecol 35: $220-221$.

Shibata E, Rajakumar A, Powers RW, Larkin RW, Gilmour C, Bodnar LM, Crombleholme WR, Ness RB, Roberts JM, Hubel CA. 2005. Soluble fms-like tyrosine kinase 1 is increased in preeclampsia but not in normotensive pregnancies with small-for-gestational-age neonates: Relationship to circulating placental growth factor. $J$ Clin Endocrinol Metab 90: 4895-4903.

Sibai B, Dekker G, Kupferminc M. 2005. Pre-eclampsia. Lancet 365: 785-799. 
Soto-Wright V, Bernstein M, Goldstein DP, Berkowitz RS 1995. The changing clinical presentation of complete molar pregnancy. Obstet Gynecol 86: 775-779.

Tayade C, Hilchie D, He H, Fang Y, Moons L, Carmeliet P, Foster RA, Croy BA. 2007. Genetic deletion of placenta growth factor in mice alters uterine NK cells. J Immuno 178: $4267-4275$

Thomas CP, Andrews JI, Liu KZ. 2007. Intronic polyadenylation signal sequences and alternate splicing generate human soluble Flt1 variants and regulate the abundance of soluble Flt1 in the placenta. FASEB J 21: 3885-3895.

Toporsian M, Gros R, Kabir MG, Vera S, Govindaraju K, Eidelman DH, Husain M, Letarte M. 2005. A role for endoglin in coupling eNOS activity and regulating vascular tone revealed in hereditary hemorrhagic telangiectasia. Circ Res 96: 684-692.

Tripathi R, Rath G, Ralhan R, Saxena S, Salhan S. 2009. Soluble and membranous vascular endothelial growth factor receptor-2 in pregnancies complicated by pre-eclampsia. Yonsei Med J 50: 656-666.

Tsatsaris V, Goffin F, Munaut C, Brichant JF, Pignon MR, Noel A, Schaaps JP, Cabrol D, Frankenne F, Foidart JM 2003. Overexpression of the soluble vascular endothelial growth factor receptor in preeclamptic patients: Pathophysiological consequences. J Clin Endocrinol Metab 88: 5555-5563.

Vatten LJ, Romundstad PR, Trichopoulos D, Skjaerven R. 2002. Pre-eclampsia in pregnancy and subsequent risk for breast cancer. Br J Cancer 87: 971-973.

Venkatesha S, Toporsian M, Lam C, Hanai J, Mammoto T, Kim YM, Bdolah Y, Lim KH, Yuan HT, Libermann TA, et al. 2006. Soluble endoglin contributes to the pathogenesis of preeclampsia. Nat Med 12: 642-649.

Vuckovic M, Ponting J, Terman BI, Niketic V, Seif MW, Kumar S. 1996. Expression of the vascular endothelial growth factor receptor, KDR, in human placenta. J Anat 188: $361-366$

Wang A, Rana S, Karumanchi SA. 2009. Preeclampsia: The role of angiogenic factors in its pathogenesis. Physiology (Bethesda) 24: 147-158

Wolf M, Shah A, Lam C, Martinez A, Smirnakis KV, Epstein FH, Taylor RN, Ecker JL, Karumanchi SA, Thadhani R. 2005. Circulating levels of the antiangiogenic marker sFLT-1 are increased in first versus second pregnancies. Am J Obstet Gynecol 193: 16-22.

Wulff C, Wilson H, Dickson SE, Wiegand SJ, Fraser HM. 2002. Hemochorial placentation in the primate: Expression of vascular endothelial growth factor, angiopoietins, and their receptors throughout pregnancy. Biol Reprod 66: 802-812.

Xuan YH, Choi YL, Shin YK, Ahn GH, Kim KH, Kim WJ, Lee HC, Kim SH. 2007. Expression of TGF-beta signaling proteins in normal placenta and gestational trophoblastic disease. Histol Histopathol 22: 227-234.

Zhang EG, Smith SK, Baker PN, Charnock-Jones DS. 2001. The regulation and localization of angiopoietin-1, -2 , and their receptor Tie2 in normal and pathologic human placentae. Mol Med 7: 624-635.

Zhao H, Wong RJ, Kalish FS, Nayak NR, Stevenson DK. 2009. Effect of heme oxygenase-1 deficiency on placental development. Placenta 30: 861-868.

Zhao S, Gu Y, Fan R, Groome LJ, Cooper D, Wang Y. 2010. Proteases and sFlt-1 release in the human placenta. Placenta 31: 512-518.

Zhou Y, Damsky CH, Fisher SJ. 1997a. Preeclampsia is associated with failure of human cytotrophoblasts to mimic a vascular adhesion phenotype. One cause of defective endovascular invasion in this syndrome? J Clin Invest 99: 2152-2164.

Zhou Y, Fisher SJ, Janatpour M, Genbacev O, Dejana E, Wheelock M, Damsky CH. 1997b. Human cytotrophoblasts adopt a vascular phenotype as they differentiate. A strategy for successful endovascular invasion? J Clin Invest 99: 2139-2151.

Zhou Y, McMaster M, Woo K, Janatpour M, Perry J, Karpanen T, Alitalo K, Damsky C, Fisher SJ. 2002. Vascular endothelial growth factor ligands and receptors that regulate human cytotrophoblast survival are dysregulated in severe preeclampsia and hemolysis, elevated liver enzymes, and low platelets syndrome. Am J Pathol 160: 1405-1423.

Zhou CC, Ahmad S, Mi T, Xia L, Abbasi S, Hewett PW, Sun C, Ahmed A, Kellems RE, Xia Y. 2007. Angiotensin II induces soluble fms-like tyrosine kinase-1 release via calcineurin signaling pathway in pregnancy. Circ Res 100: 88-95.

Zhu X, Wu S, Dahut WL, Parikh CR. 2007. Risks of proteinuria and hypertension with bevacizumab, an antibody against vascular endothelial growth factor: Systematic review and meta-analysis. Am J Kidney Dis 49: $186-193$.

Zygmunt M, Herr F, Keller-Schoenwetter S, Kunzi-Rapp K, Munstedt K, Rao CV, Lang U, Preissner KT. 2002. Characterization of human chorionic gonadotropin as a novel angiogenic factor. J Clin Endocrinol Metab 87: $5290-5296$. 


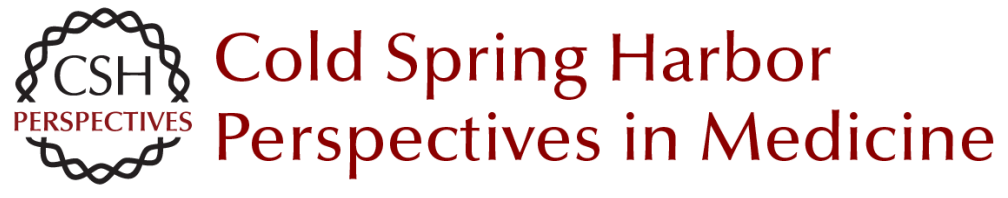

\title{
Angiogenic Factors in Preeclampsia and Related Disorders
}

\author{
Ana Sofia Cerdeira and S. Ananth Karumanchi \\ Cold Spring Harb Perspect Med 2012; doi: 10.1101/cshperspect.a006585 originally published online May \\ 23, 2012
}

\section{Subject Collection Angiogenesis}

Extracellular Matrix Regulation of Vascular Morphogenesis, Maturation, and Stabilization George E. Davis and Scott S. Kemp

Endothelial Cell-Pericyte Interactions in the Pathogenesis of Cerebral Cavernous Malformations (CCMs) Wang Min and Jenny Huanjiao Zhou

Lymphatic Clearance and Pump Function Jerome W. Breslin

Platelets and (Lymph)angiogenesis Harvey G. Roweth and Elisabeth M. Battinelli

Modeling Brain Vasculature Immune Interactions In Vitro Ruth Lyck, Hideaki Nishihara, Sidar Aydin, et al.

Human Endothelial Colony-Forming Cells Juan M. Melero-Martin

\section{The Beauty and Complexity of Blood Vessel} Patterning

Victoria L. Bautch and Yoh-suke Mukouyama

Endothelialitis, Microischemia, and

Intussusceptive Angiogenesis in COVID-19 Steven J. Mentzer, Maximilian Ackermann and Danny Jonigk
Regulation of the Blood-Brain Barrier in Health and Disease Cara C. Rada, Kanako Yuki, Jie Ding, et al.

Targeting Angiogenesis via Resolution of Inflammation

Abigail G. Kelly and Dipak Panigrahy

Notch Signaling in the Vasculature: Angiogenesis and Angiocrine Functions

Sana S. Hasan and Andreas Fischer

Signal Transduction and Gene Regulation in the Endothelium

Michel V. Levesque and Timothy Hla

Buttons and Zippers: Endothelial Junctions in

Lymphatic Vessels

Peter Baluk and Donald M. McDonald

Endothelial Cell Fate Determination: A Top Notch Job in Vascular Decision-Making

L.A. Naiche, Stephanie R. Villa and Jan K. Kitajewski

Leukocyte Trafficking in Lymphatic Vessels Aline Bauer, Hazal Tatliadim and Cornelia Halin

Lymphatic Tissue and Organ Engineering for In Vitro Modeling and In Vivo Regeneration Anna M. Kolarzyk, Gigi Wong and Esak Lee

For additional articles in this collection, see http://perspectivesinmedicine.cshlp.org/cgi/collection/ 